\title{
Thermal behavior (TG-DTA-TMA), sintering and properties of a kaolinitic clay from Buenos Aires Province, Argentina
}

\section{(Comportamento térmico (TG-DTA-TMA), sinterização e propriedades de uma argila caulinítica da Província de Buenos Aires, Argentina)}

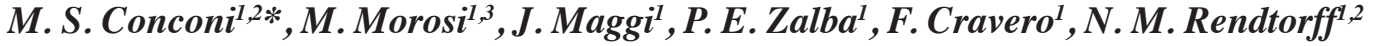 \\ ${ }^{I}$ Centro de Tecnología de Recursos Minerales y Cerámica, CIC-CONICET, \\ Cno. Centenario y 506 Gonnet, La Plata 1897, Argentina \\ ${ }^{2}$ Universidad Nacional de La Plata, Facultad de Ciencias Exactas, Departamento de Química, Argentina \\ ${ }^{3}$ Universidad Nacional de La Plata, Facultad de Ciencias Naturales y Museo, Argentina
}

\begin{abstract}
The technological properties of a local kaolin, considered as a potential industrial material, were correlated with the thermal behavior and sintering processes carried out through a series of thermochemical analyses. The chemical and mineralogical characterization of the material was carried out, together with a simple microstructural characterization. The used material corresponded to the kaolinized basement rocks (saprolite zone) mined at La Verónica quarry, Chillar area, Azul County, Argentina. The complete kaolinite-metakaolinite-spinel-mullite thermal series was characterized. Sintering behavior was studied; a viscous phase sintering mechanism was proposed. Apparent density and porosity of fired ceramics were measured. A light-firing color was confirmed by colorimetry. The viscous phase mechanism was possibly described thanks to the multi-technique thermal behavior analysis complemented by XRD analysis. These results permitted to establish formulation and processing strategies of ceramic materials based on the studied clay. The possible applications include: tile manufacturing, sanitary ware, tableware, kaolinitic proppants, chamotte and refractory materials.
\end{abstract}

Keywords: kaolinitic clay, thermal behavior, sintering, properties.

\section{Resumo}

As propriedades tecnológicas de um caulim local, considerado um potencial material industrial, foram correlacionadas com o comportamento térmico e processos de sinterização realizados por meio de uma série de análises termoquímicas. A caracterização química e mineralógica do material foi realizada, juntamente com uma simples caracterização microestrutural. O material utilizado correspondeu às rochas de base caulinizadas (zona de saprolito) extraídas na lavra de La Verónica, na região de Chillar, no Condado de Azul, Argentina. A série térmica completa caulinita-metacaulitaespinélio-mulita foi caracterizada. O comportamento de sinterização foi estudado; um mecanismo de sinterização de fase viscosa foi proposto. A densidade aparente e a porosidade das cerâmicas queimadas foram medidas. A cor de queima clara foi confirmada por colorimetria. O mecanismo de fase viscosa foi possivelmente descrito graças à análise do comportamento térmico por múltiplas técnicas complementada pela análise de DRX. Estes resultados permitiram estabelecer estratégias de formulação e processamento de materiais cerâmicos baseados na argila estudada. As possíveis aplicações incluem: fabricação de azulejos, louças sanitárias, louças, propantes cauliníticos, chamote e materiais refratários.

Palavras-chave: argila caulinítica, comportamento térmico, sinterização, propriedades.

\section{INTRODUCTION}

Kaolin is composed of any member of the kaolin group as the principal mineral phase. Kaolinite $(\mathrm{K}$ : $\mathrm{Al}_{2} \mathrm{O}_{3} \cdot 2 \mathrm{SiO}_{2} \cdot 2 \mathrm{H}_{2} \mathrm{O}$ ), the phase present at La Verónica quarry, is classified as a 1:1 dioctahedral phyllosilicate. Kaolins are

*msconconi@cetmic.unlp.edu.ar

(D) https://orcid.org/0000-0002-7221-8282 utilized in a large variety of industrial applications such as ceramics, refractories, cement, filling agent in paper, plastics, rubber, cosmetics, ceramic proppants, etc. In order to reach the desired properties, thermal treatments are involved in the majority of these applications [1-8]. Additionally, it can be utilized for waste management and preparation of geopolymers and geopolymer-based composites, zeolites and intercalates [9-13]. The classic paper from Brindley and Nakahira [1] reported for the first time a systematic 
study of phase transformations on kaolinite-mullite series up to high temperatures $\left(\sim 1400^{\circ} \mathrm{C}\right)$. The actual temperature transformations can be evaluated by several thermal analysis techniques. In fact, the particular properties of each natural raw material depend on the different geochemical constitutions of these materials including impurities, in consequence, heating rates, for example, are affected by geochemistry of each material $[2,14]$.

Depending on the particular application, different properties of kaolinitic clays become crucial. In ceramic applications, the higher amount of alumina and the lower iron and titanium oxides are correlated with the possible application in finer products or with higher refractoriness. The hardness of the clay mineral is also taken into account because it would be related to the consumed energy in the milling pretreatment. The amount and particle size of the quartz grains are also important and related to the abrasiveness property of the clay. In the majority of the applications the availability, stability and cost of the actual kaolinitic clay are decisive, as well [3]. The use of clays in tile manufacturing, hence their commercial classification, depends on the technological and appearance requirements of each kind of ceramic body: firstly the color after firing and secondly the behavior during the tilemaking process, involving properties like slip viscosity, plasticity, drying sensitivity, fusibility, pore-forming ability among the most important ones, which are strictly connected with clay mineralogy and particle size distribution [3, 15-18]. Chemical composition is commonly determined by X-ray fluorescence, the mineralogical composition is usually assessed by X-ray diffraction (XRD), and the particle size can be evaluated by laser scattering, sedigraphy or by scanning electron microscopy. Open porosity and apparent density, permanent shrinkage and color (CieLab) after firing are usually employed for quality control [19]. These are evaluated by the so-called immersion test, a simple caliper and a colorimeter [3].

The thermal behavior is usually assessed by different thermal analysis that includes, thermogravimetry, differential thermal analysis, dilatometry, or calorimetry [20-22]. The kaolinite series has been widely studied and described [20]. The sequential chemical processes are known as: i) kaolinite (K: $\mathrm{Al}_{2} \mathrm{O}_{3} .2 \mathrm{SiO}_{2} .2 \mathrm{H}_{2} \mathrm{O}$ ) surface water desorption at low temperatures $\left(100-170^{\circ} \mathrm{C}\right)$; ii) kaolinite dehydroxylation into metakaolinite (MK: $\mathrm{Al}_{2} \mathrm{O}_{3} .2 \mathrm{SiO}_{2}$ ) in the $400-650{ }^{\circ} \mathrm{C}$ range; iii) spinel-type aluminosilicate (SAS) formation and the mullite (M: $3 \mathrm{Al}_{2} \mathrm{O}_{3} .2 \mathrm{SiO}_{2}$ ) formation from $\mathrm{MK}$, that might occur above $980^{\circ} \mathrm{C}$; iv) parallel quartz $\left(\mathrm{SiO}_{2}\right)$ undergoes the reversible thermal $\alpha-\beta$ transformation at $573{ }^{\circ} \mathrm{C}$, and might transform into cristobalite, also amorphous silicon dioxide. A partial or complete dissolution may possibly occur at high temperatures. The excess non-crystalline silica from the K-MK-SAS-M formations might crystallize to cristobalite as well. Two different phases of cristobalite might be distinguished by means of their lattice cell parameters [23]. All these processes are affected by several factors that include: the particle size distribution, milling pre-treatment, heating rate, gas (oxygen) partial pressures, and the presence of mineralizers, iron oxide and/or fluxing secondary phases like feldspars or other alkali or earthen alkali-containing compounds [20, 24, 25]. If the compaction is high enough, together with the thermochemical described processes, the clay-based material undergoes a sintering process. Particularly a glassy phase mechanism has been accepted. Recently Zanelli et al. [22] have proposed a vitreous phase mechanism that differs from the first because it understands that the grains imbibing viscous phase are not completely or strictly amorphous [21, 22]. In fact, it might be understood as a silica-based non-crystalline phase with dispersed nano or submicron crystalline phases and even immiscible liquid phases and/or gas bubbles that imbibe the crystalline phases. At higher temperatures (and/or longer dwellings) it increases its apparent fluidity (decrease glass apparent viscosity) accompanied by the subsequent loss of porosity, macroscopic shrinkage and mechanical strengthening (after cooling). From the macroscopic point of view, the sintering process consists of a continuous shrinkage. This might present several stages depending on the nature of the viscous phase, the heating rate and other processing variables. These processes might be evaluated by dilatometry [21].

The aim of the present work is to deeply describe the thermal behavior of an Argentinean kaolin and to establish some technological properties of the local raw material. For this, the thermal behavior and sintering processes obtained through a series of thermochemical analyses, which include thermogravimetry (TG), differential thermal analysis (DTA) and dilatometry (TMA) are assessed and correlated. The chemical and mineralogical characterization of the material is carried out, together with a simple microstructural characterization. Finally, the mineral thermal disappearance and the thermal subsequent neo-mineralization and amorphous phase formation are also studied by XRD and is employed for describing the sintering mechanism, the multistep densification, evaluated by TMA, was explained in terms of the complementary thermal analyses and the phase evolution.

\section{MATERIAL AND METHODS}

Location and geology: in Argentina almost all the deposits that provide the raw materials for the entire ceramic bodies manufactured in Buenos Aires Province are located in the Patagonia region, which implies about 1300 to 2300 $\mathrm{km}$ of transportation, highly increasing the cost of the final product [26]. Nevertheless, in the Buenos Aires Province, the Sierras Septentrionales (Fig. 1) contain a large number of clay deposits exploited for several industrial applications. Among them, there are kaolin deposits that are residual, derived from the weathering of Precambrian basement rocks (Complejo Buenos Aires) which are unconformably covered by siliciclastic sediments of the Ordovician Balcarce Formation (orthoconglomerates and quartzites with clay intercalations [27]. The kaolin deposits are located in the Chillar area, $65 \mathrm{~km}$ southwest Olavarria city where La 
Verónica (Figs. 1 and 2) is the main site of exploitation. The weathering zones detected by mineralogical and chemical studies correspond to the saprolite (totally weathered rocks) or the saprock (partially weathered rock), depending on the site of sampling. These deposits have been exploited in several quarries aligned in an NW-SE direction which

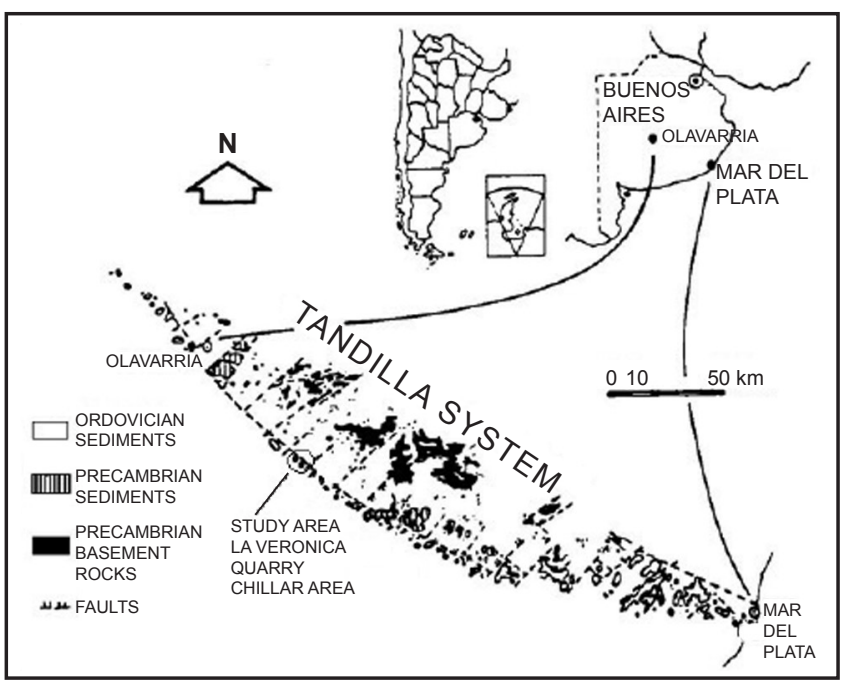

Figure 1: Geological map of Tandilia System (adapted from [27]). [Figura 1: Mapa geológico do Sistema Tandilia (adaptado de [27]).]

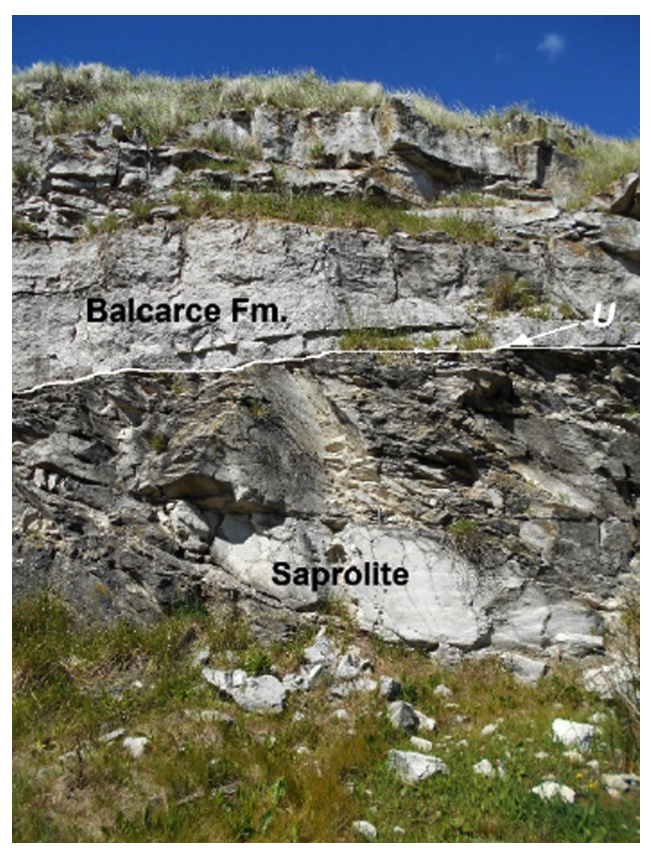

Figure 2: Photograph of weathering profile in the archeozoic crystalline basement rocks at La Verónica quarry, Chillar Sector. $\mathrm{U}$ represents the unconformity (nonconformity) which separates the weathered crystalline basement rocks of the Complejo Buenos Aires (saprolite) from the overlying sedimentary sequence of the Balcarce Formation.

[Figura 2: Fotografia do perfil de intemperismo nas rochas do subsolo cristalino arqueozoico da lavra de La Verónica, Setor Chillar. U representa a inconformidade que separa as rochas do embasamento cristalino do Complexo Buenos Aires (saprolito) da sequência sedimentar sobrejacente da Formação Balcarce.] spread along $45 \mathrm{~km}$ that include, among others, La Verónica quarry [28]. In the case of La Verónica, previous studies [29] indicate that the only existent weathering zone is the saprolite, which is lenticular and massive, with a thickness between 1 and $4 \mathrm{~m}$, reddish in color at the base and whitish to greenish at the top. The mineralogical composition of the saprolite, analyzed by X-ray diffraction is essentially kaolinitic, in some sectors of a high degree of purity, accompanied by illite. The most common impurities are quartz and anatase.

Characterization methods: since the objective of the study is to determine the kaolin ceramic behavior at a technological scale, the sampling was performed on the stockpile of La Verónica quarry in order to assure its representativeness. The $20 \mathrm{~kg}$ sample was crushed, mixed, quartered and milled at the laboratory until all the material passed through a 200-mesh sieve. The chemical composition was evaluated by inductively coupled plasma atomic emission spectroscopy (ICP-AES), after triacid [30]. The effect of heat treatment was evaluated by thermogravimetric and differential thermal analysis (TG-DTA) simultaneously carried out in a Rigaku Evo II equipment with $10^{\circ} \mathrm{C} / \mathrm{min}$ as the heating rate in Pt crucible, in air atmosphere [31,32]. To understand the sintering behavior, thermomechanical analysis (TMA) on vertical prismatic $\left(20.0 \times 3.5 \times 3.5 \mathrm{~mm}^{3}\right)$ sample was performed; this was performed with $10{ }^{\circ} \mathrm{C} / \mathrm{min}$ heating rate in an air atmosphere (Rigaku, Evo Plus II, Japan). Samples were shaped with a slab roller, in plastic conditions. The final geometry was achieved by grinding with sandpaper after drying. The starting compaction grade was around $55 \%$, estimated by volumetric density. For sintering and crystalline phase thermal evolution tests, samples were fired in an electric furnace with a heating rate of $10{ }^{\circ} \mathrm{C} / \mathrm{min}$ and 30 min dwelling, at $800,1000,1200,1300$ and $1400{ }^{\circ} \mathrm{C}$. Afterward, the Archimedes immersion method was carried out for calculating apparent density and open porosity of the fired samples. These two sintering parameters illustrate the actual sintering grade of the resulting materials. Identification and quantification of crystalline phases in the fired materials were carried out by X-ray diffraction (XRD, Philips, 3020, with $\mathrm{CuK} \alpha$ radiation, $\mathrm{Ni}$ filter, at $40 \mathrm{kV}-35 \mathrm{~mA}$, with $0.04^{\circ}$ and $2 \mathrm{~s}$ steps in the $3^{\circ}-70^{\circ}$ range). Phase identification from XRD patterns was carried out using the PDF-2 database (ICDD PDF-2). Patterns were analyzed with the program FullProf (v. 5.80-2016) which is a multipurpose profilefitting program [33, 34], including Rietveld refinement to perform phase quantification [35]. The employed quantification method comprised both crystalline and noncrystalline phases. Particularly the amorphous glassy phase was quantified by the so-called Le Bail approach, in which this phase is introduced in the refinement as crystalline silica with extremely low crystallite size [36, 37]. Finally, the microstructure analysis was performed by a scanning electron microscope (SEM, Jeol, JCM-6000); a gold-coated free fracture surface was analyzed. The CieLab color of the fired ceramic samples was evaluated by a Minolta CR-400 colorimeter. 


\section{RESULTS AND DISCUSSION}

Mineralogical and chemical composition of the Chillar kaolin: chemical and mineralogical compositions of the Chillar kaolin (Chillar 0) are shown in Tables I and II. Phase identification performed by XRD analysis determined the presence of kaolinite as the main component (Fig. 3). The evaluated amount of kaolinite confirmed the raw material classification. Quartz was the principal secondary crystalline phase. Illite was also present; finally, some traces of titanium oxide were detected. The evaluated loss on ignition ( $\mathrm{LOI}=9.1 \mathrm{wt} \%$ ) corresponded to $65 \%$ of kaolinite, assuming a theoretical kaolinite LOI of $\sim 13.9 \mathrm{wt} \%$. The difference with the kaolinite content evaluated by XRD and quantified by the Rietveld refinement (Table II) is within the method uncertainty. Based on the low iron content, the clay might be classified as white clay but discourages translucent porcelain application. It can be classified as light-firing clay (ISO 13006). Actual mineralogical composition of the saprolite is the result of the original basement rock mineralogical composition, plus the occurred superimposed weathering processes. As it is well known, in the saprolite zone most of the original minerals do not exist anymore. According to previous studies in the bedrock and the saprock, these original minerals were oligoclase (17\%-22\%), quartz, biotite, hornblende and minor apatite, and the rock is classified as biotitic tonalite [28]. Plagioclase has altered to kaolinite, hornblende transforms to smectite and smectite to illite up in the profile. Kaolinite books, mostly, lose definition and become 'ghostly' by diagenetic dissolution (Fig. 4). The saprolite is compact, with conchoidal fracture and reddishgrey to grey-green colored, occasionally reddish to the base due to the presence of iron oxides and hydroxides. This fact is normal in a vertical weathering profile because $\mathrm{Fe}$ is one of the first oxides which are lost from base to top. The greenish gray color is due to the clay minerals. The impurities are represented by quartz and traces of anatase [28].

The $\mathrm{Al}_{2} \mathrm{O}_{3}$ content $(25.89 \%)$ was consistent with data obtained from previous studies on the saprolite at $\mathrm{La}$ Verónica quarry, Chillar area [29], where $\mathrm{Al}_{2} \mathrm{O}_{3}$ (28.9\%$31.9 \%$ ) is due to the destruction of plagioclase and mica and to the concentration of $\mathrm{Al}_{2} \mathrm{O}_{3}$ in the neoformed clay minerals (kaolinite). Low $\mathrm{K}_{2} \mathrm{O}$ content $(0.78 \%)$ was consistent with the destruction of micas and loss of $\mathrm{K}^{+}$during weathering. $\mathrm{SiO}_{2}$ content corresponded to the transformation of original silicates into clay minerals and the remnant initial quartz. The low $\mathrm{Fe}_{2} \mathrm{O}_{3}$ content $(0.67 \%)$ is explained because iron contained in the mica is the first element which solubilizes in a weathering profile. The low $\mathrm{Na}_{2} \mathrm{O}, \mathrm{MgO}$ and $\mathrm{CaO}$ contents $(0.02 \%, 0.13 \%$ and $0.13 \%$, respectively) corresponded
Table II - Mineralogical composition of the studied clay (Chillar 0).

[Tabela II - Composição mineralógica da argila estudada (Chillar 0).]

\begin{tabular}{cccc}
\hline Quartz $^{1}$ & Kaolinite $^{2}$ & Illite $^{3}$ & Anatase $^{4}$ \\
\hline $24.5(8)$ & $66.2(11)$ & $6.7(5)$ & $2.7(5)$ \\
\hline
\end{tabular}

PDF file: ${ }^{1}$ 01-085-0797, ${ }^{2}$ 01-080-0885, ${ }^{3} 00-026-0911,{ }^{4} 01-071-1166$; values in parenthesis represent estimated standard deviations in the last quoted place calculated by Fullprof.

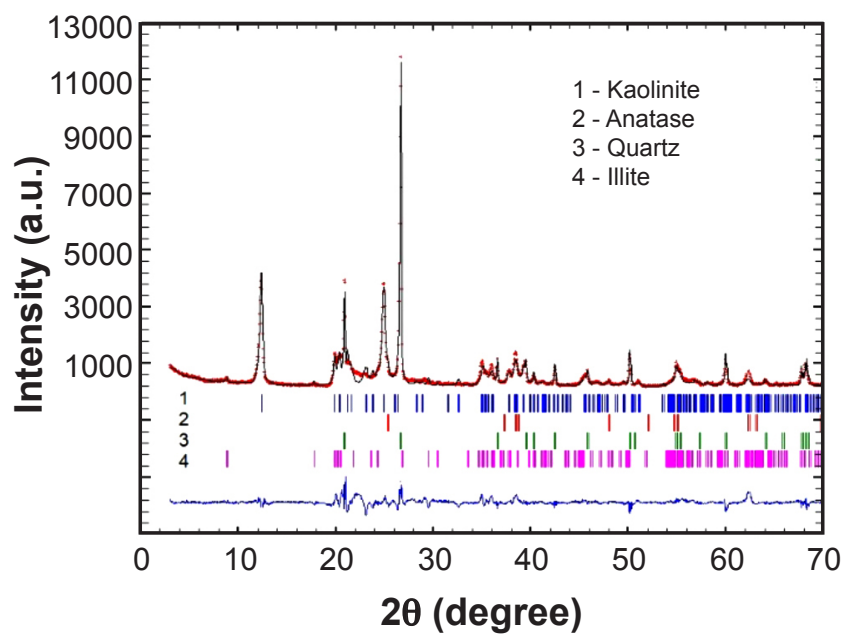

Figure 3: XRD pattern and Rietveld refinement of Chillar 0 sample. Vertical lines correspond to identified phases.

[Figura 3: Padrão de DRX e refinamento de Rietveld da amostra de Chillar 0. Linhas verticais correspondem às fases identificadas.]

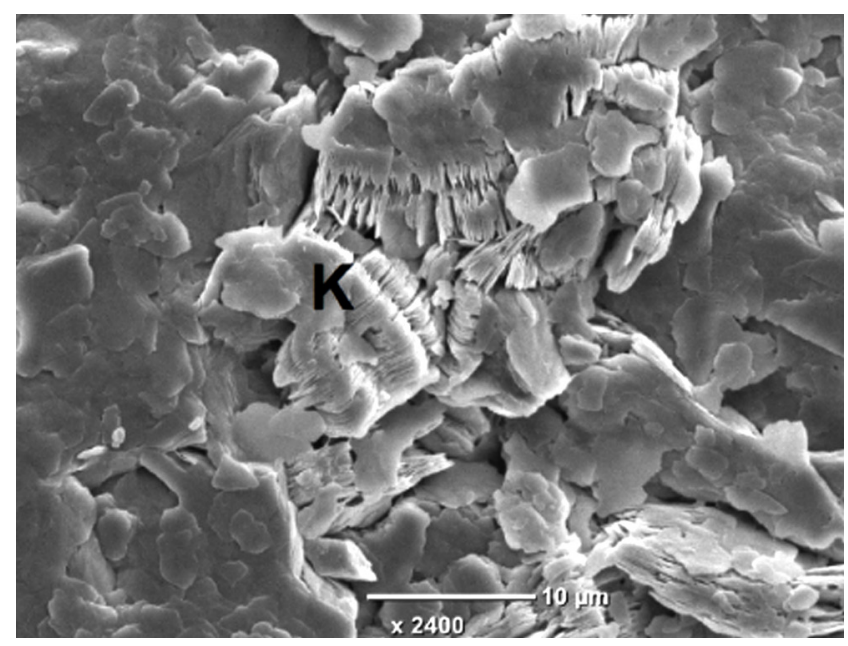

Figure 4: Scanning electron micrograph showing 'accordions' of hexagonal kaolinite.

[Figura 4: Micrografia eletrônica de varredura mostrando 'acordeões' de caulinita hexagonal.]

Table I - Chemical composition (wt\%) of the studied clay (ICP-AES).

[Tabela I - Composição química (\% em massa) da argila estudada (ICP-AES).]

\begin{tabular}{llllllllll}
\hline $\mathrm{SiO}_{2}$ & $\mathrm{Al}_{2} \mathrm{O}_{3}$ & $\mathrm{Fe}_{2} \mathrm{O}_{3}$ & $\mathrm{MgO}$ & $\mathrm{CaO}$ & $\mathrm{Na}_{2} \mathrm{O}$ & $\mathrm{K}_{2} \mathrm{O}$ & $\mathrm{TiO}_{2}$ & $\mathrm{P}_{2} \mathrm{O}_{5}$ & LOI* $^{*}$ \\
\hline 62.19 & 25.89 & 0.67 & 0.13 & 0.13 & 0.02 & 0.78 & 1.01 & 0.05 & 9.1 \\
\hline * loss on ignition. & & & & & & & &
\end{tabular}


also to the loss of these elements in a weathering profile. Previous studies on the zone [28] showed that the $\mathrm{TiO}_{2}$ value for the saprolite was $0.88 \%$. As the $\mathrm{TiO}_{2}$ found in this case was slightly higher, it is assumed that its relative increase was due to the presence of anatase as a resistant mineral in the uppermost section of the saprolite. $\mathrm{P}_{2} \mathrm{O}_{5}$ content $(0.05 \%)$ in the saprolite was very low compared to the mean values obtained for granitic rocks $(0.375 \%)$ [38]. As $\mathrm{P}_{2} \mathrm{O}_{5}$ concentrates in apatite minerals, this value corroborated that there was little apatite in the bedrock. Moreover, the $\mathrm{P}_{2} \mathrm{O}_{5}$ mobilized up in the weathering profile as there were no organisms capable of retaining it in the saprolite. In general, all these data coincide with the previous chemical analyses performed.

Scanning electron microscopy of the studied clay: the SEM image in Fig. 4 shows a homogeneous small grain size, below $5 \mu \mathrm{m}$. Platelet morphology is clear. Moreover, aggregates of hexagonal diagenetic kaolinite plates can be devised but the edges show some breakage.

Thermalbehaviorof thestudiedkaolin. Thermogravimetry (TG) and differential thermal analysis (DTA): Fig. 5 shows the obtained TG and DTA curves. The thermal behavior observed was similar to other kaolinitic clays [39-44]. The mass loss corresponding to surface water $\left(25-100^{\circ} \mathrm{C}\right)$ can be observed; this was $\sim 2 \mathrm{wt} \%$. The chemical water mass loss $\left(450-750^{\circ} \mathrm{C}\right)$ was around $\sim 8.5 \mathrm{wt} \%$. This was coherent with the clay fraction content (Table II). The differential thermal analysis revealed the same thermal processes with two endothermic peaks $\left(100\right.$ and $\left.514{ }^{\circ} \mathrm{C}\right)$. At higher temperature $\left(\sim 985{ }^{\circ} \mathrm{C}\right)$ the spinel-type aluminosilicate phase plus primary mullite formation process was evidenced by means of a small exothermic peak. Finally, secondary mullite formation, usually detected by a couple of exothermic small peaks in the $1100-1240{ }^{\circ} \mathrm{C}$ range [43, 45], was scarcely detected in the studied clay (Fig. 5).

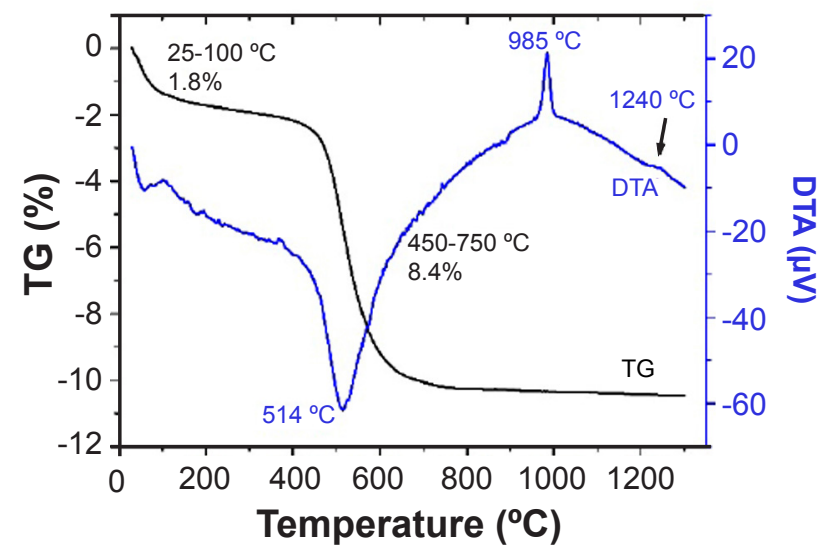

Figure 5: Thermogravimetric (TG) and differential thermal analysis (DTA) curves of the studied kaolinitic clay (Chillar 0).

[Figura 5: Curvas termogravimétricas (TG) e de análise térmica diferencial (DTA) da argila caulinitica estudada (Chillar 0).]

Thermomechanical analysis (TMA): TMA, also known as dilatometry, was carried out in reversible mode, one up to $1040{ }^{\circ} \mathrm{C}$ and the second one in a complete cycle up to $1400{ }^{\circ} \mathrm{C}$ (Fig. 6). These corresponded to the typical industrial temperatures used to fire earthenware and grog or chamotte. The macroscopic thermal behavior of clay and clay mixtures was recently fully described in [22]; the present studied material revealed a similar behavior. A thermal expansion (positive slope in the TMA) range was observed in both curves, from room temperature to $550^{\circ} \mathrm{C}$. At this temperature, an inflection was observed and after it, the samples started a minor shrinkage stage up to $\sim 950{ }^{\circ} \mathrm{C}$, where an abrupt $\sim 1 \%$ sigmoidal shrinkage was associated to the DTA spinel-type aluminosilicate formation peak (Fig. 5). After this, the curve presented a slight shrinkage stage that finished at $1100^{\circ} \mathrm{C}$; at this temperature, the viscous sintering of the ball clay started $[21,22]$. This process ended at around $1360{ }^{\circ} \mathrm{C}$ where the sintering finished. Apparently, this stage can be divided into two steps, observed in the derivative TMA (dTMA) curve in the $700-1400{ }^{\circ} \mathrm{C}$ range (Fig. 7). The final stage of the TMA test presented no dimension change from 1360 up to $1400{ }^{\circ} \mathrm{C}$. In the dTMA curve, a

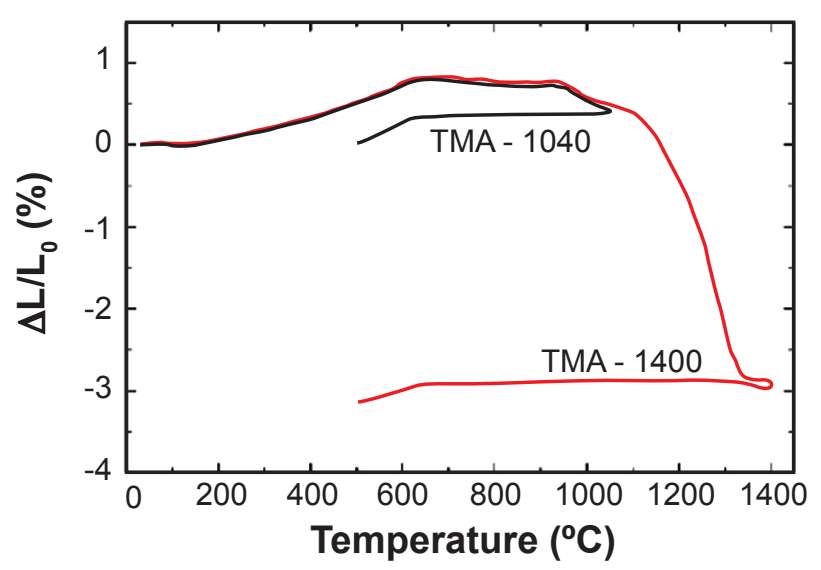

Figure 6: Thermomechanical analysis (TMA) sintering curves of Chillar 0 sample up to 1040 and $1400{ }^{\circ} \mathrm{C}$.

[Figura 6: Curvas de sinterização da análise termomecânica (TMA) da amostra Chillar 0 até 1040 e $1400^{\circ} \mathrm{C}$.]

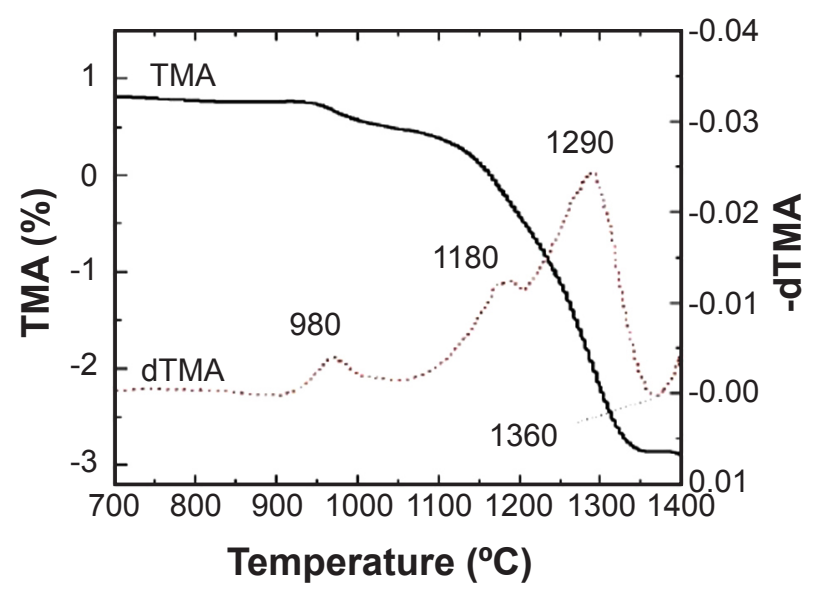

Figure 7: Thermomechanical analysis (TMA) and its derivative (dTMA) curves of the studied clay (Chillar 0) in the $700-1400{ }^{\circ} \mathrm{C}$ range.

[Figura 7: Curvas de análise termomecânica (TMA) e sua derivada (dTMA) da argila estudada (Chillar 0) na faixa 700-1400 ${ }^{\circ} \mathrm{C}$.] 


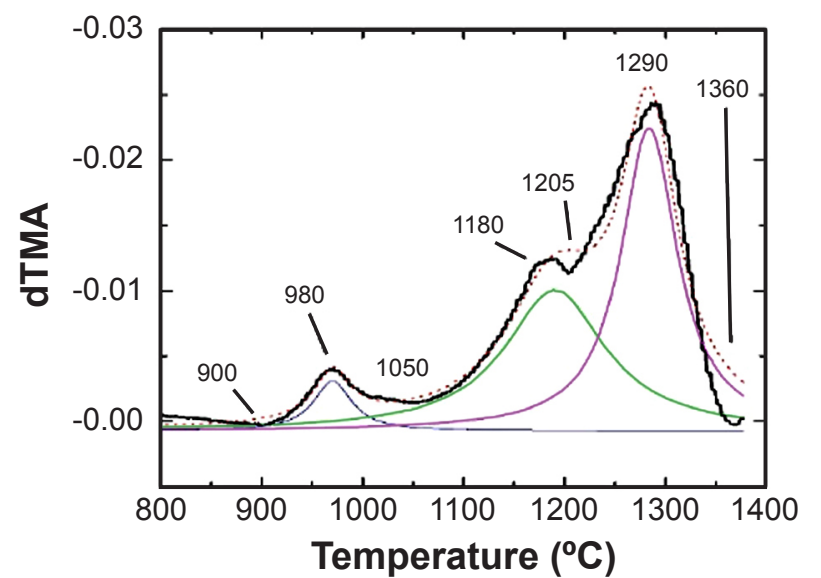

Figure 8: Detail of the derivative TMA (dTMA) curve in the 800-1400 ${ }^{\circ} \mathrm{C}$ range (-); local maximums are pointed out and a three Gaussian deconvolution (- - -) is plotted as well. Individual deconvoluted peaks are plotted separately.

[Figura 8: Detalhe da curva derivada de TMA (dTMA) na faixa 800-1400 ${ }^{\circ} \mathrm{C}$ (一); máximos locais são indicados e uma deconvolução de três Gaussianas (- -) também é plotada. Picos individuais deconvoluidos são plotados separadamente.]

3 -stage sintering process was easily observed; the maximum values, which corresponded to the shrinkage inflections were 980,1180 and $1290{ }^{\circ} \mathrm{C}$. The dTMA individual peaks were deconvoluted with Gaussian curves (Fig. 8); this fitting presented high goodness $\left(\mathrm{R}^{2}=0.992\right)$. The changes in the sintering rate might be associated with the increase of the viscous phase fluidity. It is well known that this is proportional to the temperature.

Crystalline and non-crystalline thermal phase evolution, an XRD analysis: finished ceramic products, commonly fired at a maximum temperature in the $1200-1350{ }^{\circ} \mathrm{C}$ range, contained essentially a vitreous phase associated with mullite, quartz and cristobalite $[46,47]$. Generally, all the complementary metals-like potassium, sodium, calcium, magnesium, lithium, iron, etc. are dissolved in the viscous phase $[22,39]$; in this case, the amount of these metals was low. XRD patterns of the untreated kaolin and samples fired in the $800-1400{ }^{\circ} \mathrm{C}$ range showed that quartz was present in all samples (Fig. 9). The phase evolution corresponded with bibliographic references: mullite and cristobalite peaks and the glass band appeared after higher temperature treatments. Kaolinite was not present in fired samples, verifying its decomposition. Spinel-type aluminosilicate (SAS) was present at intermediate temperature treatments.

The results of the Rietveld refinement quantification including Rwp Rietveld residuals and PDF files for each phase are shown and compared in Table III. The Rwp values were adequate and similar to the ones achieved in similar materials [48-53]. The results were concordant with the thermal analyses (TG, DTA) [20]. For the clay phases, kaolinite gave place to amorphous metakaolinite at $800{ }^{\circ} \mathrm{C}$ treatment, and the illite dehydroxylation occurred at higher temperatures. At $980^{\circ} \mathrm{C} \mathrm{SAS}$ and mullite were formed. SAS was only observed in the $1000^{\circ} \mathrm{C}$ sample. Amorphous glassy phase was also observed at $800{ }^{\circ} \mathrm{C}$ treatment and above.

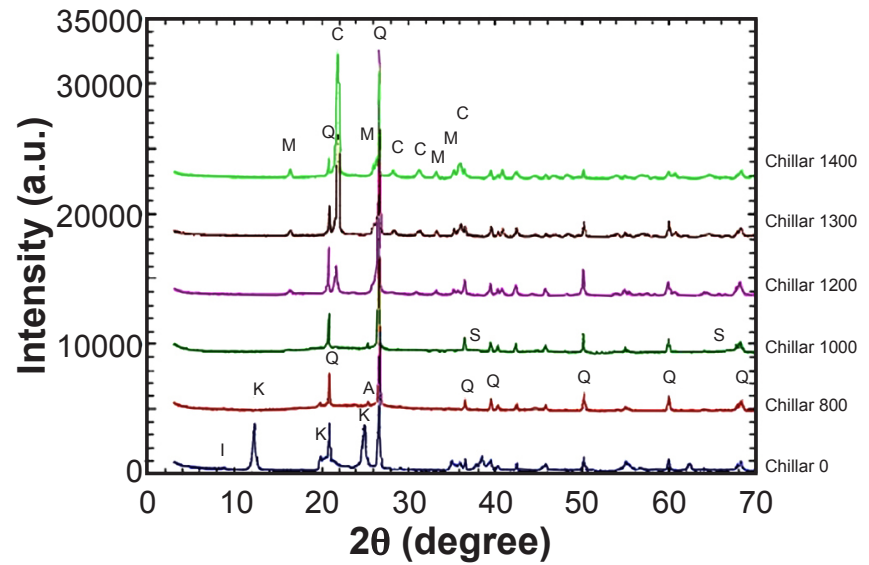

Figure 9: XRD patterns of the fired kaolin samples; principal reflections are labeled. Q-quartz, K-kaolinite, I-illite, M-mullite, C-cristobalite, S-SAS, A-anatase.

[Figura 9: Padrões de DRX das amostras de caulim sinterizadas; reflexões principais são rotuladas. Q-quartzo, $K$-caulinita, I-ilita, $M$-mulita, C-cristobalita, $S$-AS (aluminossilicato tipo espinélio), A-anatásio.]

Over $21 \%$ of mullite was evaluated after higher temperature treatments $\left(1200\right.$ and $1400{ }^{\circ} \mathrm{C}$, Table III). At $1300{ }^{\circ} \mathrm{C}$, quartz partially dissolved and transformed into cristobalite. Titanium oxide phases were only detected as traces; below $1000{ }^{\circ} \mathrm{C}$, reflections corresponded with anatase and from $1000-1300^{\circ} \mathrm{C}$ with rutile. The shape of the cristobalite peaks could not be satisfactorily fitted by a lonely contribution. Two different cristobalite structures were proposed for the Rietveld refinement. This was previously reported for similar materials [54]. This might be explained by the coexistence of two dissimilar phases: one produced from the kaolinite thermal decomposition (a) and the other from the thermal transformation of the initial quartz present in the clay mineral (b); the second presented minor impurities content, and hence smaller cell parameters. Both cristobalites were quantified separately and reported in Table III.

As mentioned above the sintering process occurred in three stages (inflections), illustrated by peaks in the dTMA curve (Fig. 8). These might be related to the phase evolution content shown in Fig. 10 (stack bar plot). It is well known that the viscosity of a silica-based glass gradually decreases with temperature once the glass transition temperature $\left(\mathrm{T}_{\mathrm{g}}\right)$ is reached. It can stand that the sintering process is related to the viscous phase fluidity [22]. If the viscous phase is a homogeneous phase, the sintering process is homogeneous with the temperature (or dwelling) advance. It is worth to point out that in this case each sintering stage (inflection in the TMA curve) included a crystalline phase transformation: the first one involved the silico-aluminate spinel-type neo-mineral (SAS); the second one involved the mullite formation from SAS and mullite crystallization from the amorphous, non-diffracting, glassy phase; and the third stage involved the cristobalite appearance, from quartz thermal transformation and after the crystallization from the amorphous glassy phase. After this, we propose that the 
Table III - Rietveld method quantification results.

[Tabela III - Resultados da quantificação pelo método de Rietveld.]

\begin{tabular}{ccccccc}
\hline Sample & Chillar 0 & Chillar 800 & Chillar 1000 & Chillar 1200 & Chillar 1300 & Chillar 1400 \\
\hline Quartz $^{1}$ & $24.5(5)$ & $39.9(6)$ & $45.0(5)$ & $45.0(6)$ & $30.6(6)$ & $18.2(3)$ \\
Kaolinite $^{2}$ & $66.2(2)$ & & & & & \\
Illite $^{3}$ & $6.7(6)$ & $3.6(4)$ & & & & \\
Anatase $^{4}$ & $2.7(4)$ & $1.5(4)$ & $1.0(3)$ & & & \\
Mullite $^{5}$ & & & & $21.6(5)$ & $21.1(5)$ & $21.3(4)$ \\
Amorphous & & $55.0(7)$ & $49.0(6)$ & $20.2(5)$ & $8.10(5)$ & $8.37(5)$ \\
SAS $^{*}$ & & $5.0(3)$ & $\operatorname{tr}$ & & \\
Cristobalite & & & (a) $8.7(6)$ & (a) $21.9(8)$ & (a) $39.5(9)$ \\
Rutile $^{7}$ & & & (b) $3.8(4)$ & (b) $18.2(8)$ & (b) $12.6(7)$ \\
Rwp & 23.9 & 17.0 & 17.1 & $\operatorname{tr}$ & $\operatorname{tr}$ & \\
& & & & 15.9 & 18.0 & 17.8 \\
\hline
\end{tabular}

PDF file: ${ }^{1}$ 01-085-0797, ${ }^{2}$ 00-029-1488, ${ }^{3}$ 00-026-0911, ${ }^{4} 01-083-2243,{ }^{5} 00-015-0776,{ }^{6} 01-082-0512,{ }^{7} 00-001-1292 ; *{ }^{*}$ spinel-type aluminosilicate [45]; (a) and (b): two different cristobalite structures; tr: trace; values in parenthesis represent estimated standard deviations in the last quoted place calculated by Fullprof.

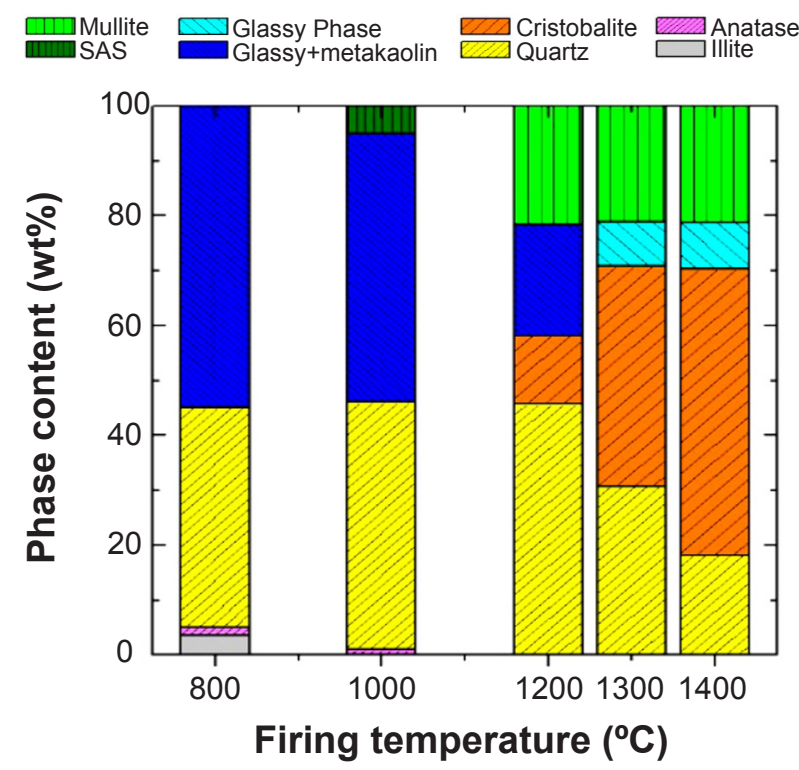

Figure 10: Phase contents as a function of the firing temperature; quantification obtained by XRD patterns and Rietveld method. [Figura 10: Teores de fases em função da temperatura de sinterização; quantificação obtida pelos padrões de DRX e método de Rietveld.]

shape of the sintering curve was related to the crystalline phase evolution. Due to the high refractoriness of the studied clay, full densification (with null porosity) was not achieved. This can only be achieved through the formulation of the material with second and third mineralizes or fluxing agents.

Sintering: open porosity and apparent density of the studied clay as a function of the firing temperature (1000, 1200 and $1400^{\circ} \mathrm{C}$ ): as mentioned, the sintering grade of the studied clay was relatively low (only $\sim 6 \%$ of linear shrinkage after firing at $1400{ }^{\circ} \mathrm{C}$ ), showing the high refractoriness of the clay, concordant with the alumina content and the low proportion of alkali and alkaline earth oxides (Table I).

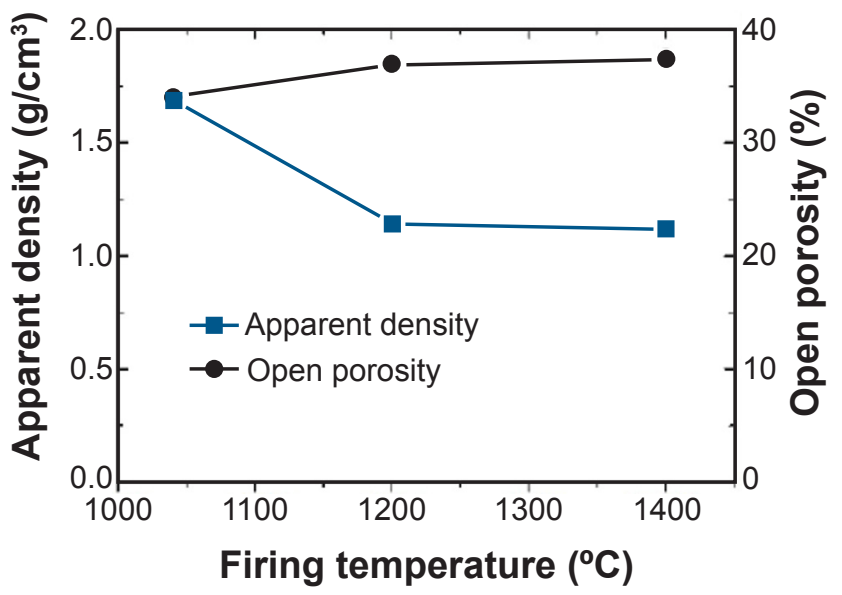

Figure 11: Textural properties (open porosity and apparent density) of the obtained ceramic samples as a function of firing temperature. [Figura 11: Propriedades texturais (porosidade aberta e densidade aparente) das amostras cerâmicas obtidas em função da temperatura de sinterização.]

Textural parameters, open porosity and apparent density, as a function of the firing temperature are plotted in Fig. 11. The achieved apparent density was $\sim 1.8 \mathrm{~g} / \mathrm{cm}^{3}$ and was obtained after a $1200{ }^{\circ} \mathrm{C}$ sintering. Higher temperatures did not improve the density. Similar results were observed for the open porosity: the lowest obtained value was $22 \%$. These results confirmed the high refractoriness of the studied clay; above this temperature the macroscopic shrinkage was not accompanied by a decrease in the open porosity. This fact inferred the generation of close porosity; in the TMA test, it was observed a de-sintering process that started at $\sim 1300{ }^{\circ} \mathrm{C}$ (Fig. 6).

Color after firing: finally, the color was assessed; ceramic bodies are distinguished in light-firing (from white to light brown) and dark-firing (from pink to dark brown) on the basis of color after firing. This color depends 
essentially on the iron oxide content, even if a certain role is played by further components (as $\mathrm{TiO}_{2}$ and $\mathrm{CaO}$ ) that may turn the color to yellowish or pinkish shades. Overall, clays used in light-firing and dark-firing bodies are fairly well discriminated by a $\mathrm{Fe}_{2} \mathrm{O}_{3}$ content of approximately 3 wt $\%$ [3]. At any rate, such a threshold is somewhat related with technological properties: the iron content of kaolin utilized to whiten a given body, for instance, is acceptable for values well below the limit (e.g., $1 \% \mathrm{Fe}_{2} \mathrm{O}_{3}$ ) [3]. In the ceramic industry, the CIELab* method is the most utilized to determine the whiteness and the color of the tiles by measuring the three parameters $L^{*}$ (lightness), from absolute white $\mathrm{L}=100$ to absolute black $\mathrm{L}=0, \mathrm{a}^{*}$ (green-red) and $\mathrm{b}^{*}$ (blue-yellow) elaborated from the visible spectra [55]. The measured values for the studied materials after different firing schedules in air atmosphere are shown in Table IV. The slight change in $\mathrm{a}$ and $\mathrm{b}$ parameters can be explained by the iron presence in the starting clay, that is dissolved in the glassy phase formed at higher temperatures. A light grey color was identified. The lightness (L) and the measured $\mathrm{a}$ and $\mathrm{b}$ values showed that the studied clay is suitable for many industrial applications in the group I, II and III of the ISO 13006 standard [3].

Table IV - CieLab coordinate of the fired samples.

[Tabela IV - Coordenada CieLab das amostras sinterizadas.]

\begin{tabular}{cccc}
\hline Firing temperature $\left({ }^{\circ} \mathrm{C}\right)$ & $\mathrm{L}$ & $\mathrm{a}$ & $\mathrm{b}$ \\
\hline 1000 & 85.4 & 0.4 & 12.0 \\
1200 & 85.3 & 1.2 & 10.5 \\
1400 & 85.4 & 2.5 & 8.3 \\
\hline
\end{tabular}

\section{CONCLUSIONS}

Chemical and mineralogical characterization of a local kaolin of industrial potential confirmed kaolinite as the principal component ( $>60 \mathrm{wt} \%$ ) accompanied by some illite and quartz ( $\sim 6$ and $\sim 25 \mathrm{wt} \%$, respectively). The multiple thermal analysis carried out permitted to understand and identify all the processes from room temperature up to 1400 ${ }^{\circ} \mathrm{C}$. Sintering behavior was studied, which started at $1000^{\circ} \mathrm{C}$ and finished at $1300^{\circ} \mathrm{C}$; a viscous phase sintering mechanism was proposed. Apparent density and open porosity of fired ceramics revealed that at $1200{ }^{\circ} \mathrm{C}$ maximum densification was reached; the formation of close porosity started at this temperature. The mineral thermal disappearance and the thermal subsequent neo-mineralization and amorphous phase formation were correlated with the multistep viscous phase sintering mechanism: the first one involved the silicoaluminate spinel-type (SAS) formation, the second one involved the mullite formation from SAS and mullite crystallization from the glassy phase, and the third stage corresponded to the cristobalite appearance. This mechanism might be extrapolated to another clay-based material analysis. A light-grey firing color was due to the presence of more than $1 \mathrm{wt} \%$ of $\mathrm{TiO}_{2}$ (anatase) inherited from the original basement rocks (biotitic tonalite). The obtained results permitted to establish formulation and processing strategies of ceramic materials based on the studied clay. The possible applications include: tile manufacturing [groups I, II and III (ISO 13006)], sanitary ware, tableware, kaolinitic proppants, chamotte and refractory materials.

\section{ACKNOWLEDGMENT}

This study was partially financed by Programa para el Fortalecimiento de Centros propios y asociados de la Comisión de investigaciones Científicas de la Pcia. de Buenos Aires - FCCIC16 (2016-2017).

\section{REFERENCES}

[1] G.W. Brindley, M. Nakahira, J. Am. Ceram. Soc. 42 (1959) 314.

[2] A.K. Chakraborty, Phase transformation of kaolinite clay, Springer, India (2014).

[3] M. Dondi, M. Raimondo, C. Zanelli, Appl. Clay Sci. 96 (2014) 91.

[4] W.E. Lee, G.P. Souza, C.J. McConville, T. Tarvornpanich, Y. Iqbal, J. Eur. Ceram. Soc. 28 (2008) 465.

[5] F. Liang, M. Sayed, G.A. Al-Muntasheri, F.F. Chang, L. Li, Petroleum 2 (2016) 26.

[6] P. Liu, Appl. Clay Sci. 38 (2007) 64.

[7] M.P. Riccardi, B. Messiga, P. Duminuco, Appl. Clay Sci. 15 (1999) 393.

[8] J.H. She, T. Ohji, Mater. Chem. Phys. 80 (2003) 610.

[9] A. Elimbi, H.K. Tchakoute, D. Njopwouo, Constr. Build. Mater. 25 (2011) 2805.

[10] C.Y. Heah, H. Kamarudin, A.M.M.A. Bakri, M. Bnhussain, M. Luqman, I.K. Nizar, C.M. Ruzaidi, Y.M. Liew, Int. J. Miner. Metall. Mater. 20 (2013) 313.

[11] M. Naghsh, K. Shams, Appl. Clay Sci. 146 (2017) 238. [12] Z. Yunsheng, S. Wei, L. Zongjin, Appl. Clay Sci. 47 (2010) 271.

[13] Z. Zuhua, Y. Xiao, Z. Huajun, C. Yue, Appl. Clay Sci. 43 (2009) 218.

[14] L. Andrini, M.R. Gauna, M.S. Conconi, G. Suarez, F.G. Requejo, E.F. Aglietti, N.M. Rendtorff, Appl. Clay Sci. 124125 (2016) 39.

[15] M. Bal, H.G. Fiederling-Kapteinat, Tile Brick Int. Man. (2007) 36.

[16] M. Dondi, Appl. Clay Sci. 15 (1999) 337.

[17] M.J. Stentiford, Int. Ceram. J. (2005) 49.

[18] I.P. Brito, E.P. Almeida, G.A. Neves, R.R. Menezes, V.J. Silva, L.N.L. Santana, Cerâmica 61, 360 (2015) 391.

[19] F. Bondioli, T. Manfredini, M. Romagnoli, J. Eur. Ceram. Soc. 26 (2006) 311.

[20] A.K. Chakraborty, in: Phase Transform. Kaolinite Clay, Springer, New Delhi (2014) 13.

[21] A. Salem, S.H. Jazayeri, E. Rastelli, G. Timellini, J. Mater. Process. Technol. 209 (2009) 1240.

[22] C. Zanelli, M. Raimondo, G. Guarini, M. Dondi, J. Non-Cryst. Solids 357 (2011) 3251. 
[23] M.A. Butler, D.J. Dyson, J. Appl. Crystallogr. 30 (1997) 467.

[24] O. Castelein, B. Soulestin, J.P. Bonnet, P. Blanchart, Ceram. Int. 27 (2001) 517.

[25] S. Chandrasekhar, S. Ramaswamy, Appl. Clay Sci. 21 (2002) 133.

[26] E. Dominguez, F. Cravero, in: Recur. Miner. Repúb. Argent., E.O. Zappettini, Inst. Geol. Recur. Miner., Secr. Est. Geol. Miner. Argent., Argentina (1999) 1265.

[27] A.M. Iñiguez Rodriguez, A. del Valle, D. Poire, L. Spalletti, P.E. Zalba, in: Cuencas Sediment. Argent., G. Chelbi, L. Spalletti (Eds.), Insugeo (1989) 245.

[28] A.M. Iñiguez Rodriguez, P.E. Zalba, R.R. Andreis, in: Proc. IX Int. Clay Conf., Strasbourg (1990) 85.

[29] P.E. Zalba, M.E. Morosi, M.S. Conconi, Gondwana industrial clays: Tandilia System, Argentina-geology and applications, Springer (2016).

[30] J.E. Kogel, S.A. Lewis, Clays Clay Miner. 49 (2001) 387.

[31] M.R. Gauna, N.M. Rendtorff, M.S. Conconi, G. Suárez, A. Pasquevich, P.C. Rivas, L. Damonte, Ceram. Int. 43 (2017) 11929.

[32] J.M. Cartaxo, P. de M. Bastos, L.N.L. Santana, R.R. Menezes, G.A. Neves, H.C. Ferreira, Cerâmica 62, 364 (2016) 338 .

[33] J. Rodríguez-Carvajal, Phys. B Condens. Matter. 192 (1993) 55.

[34] T. Roisnel, J. Rodríguez-Carvajal, Mater. Sci. Forum 378-381 (2001) 118.

[35] H.M. Rietveld, J. Appl. Crystallogr. 2 (1969) 65.

[36] M.S. Conconi, M.R. Gauna, M.F. Serra, G. Suarez, E.F. Aglietti, N.M. Rendtorff, Cerâmica 60, 356 (2014) 524.

[37] A. Le Bail, J. Non-Cryst. Solids 183 (1995) 39.

[38] F. Horton, Geochem. Geophys. Geosyst. 16 (2015) 1723.
[39] W.M. Carty, U. Senapati, J. Am. Ceram. Soc. 81 (1998) 3. [40] A.H. De Aza, X. Turrillas, M.A. Rodriguez, T. Duran, P. Pena, J. Eur. Ceram. Soc. 34 (2014) 1409.

[41] M.F. Hernández, M.S. Conconi, M. Cipollone, M.S. Herrera, N.M. Rendtorff, Appl. Clay Sci. 146 (2017) 380.

[42] K.J.D. MacKenzie, R.H. Meinhold, I.W.M. Brown, G.V. White, J. Eur. Ceram. Soc. 16 (1996) 115.

[43] K. Okada, N. ŌTsuka, J. Ossaka, J. Am. Ceram. Soc. 69 (1986) C-251.

[44] K. Srikrishna, G. Thomas, R. Martinez, M.P. Corral, S.D. Aza, J.S. Moya, J. Mater. Sci. 25 (1990) 607.

[45] H. Schneider, J. Schreuer, B. Hildmann, J. Eur. Ceram. Soc. 28 (2008) 329.

[46] M. Bellotto, A. Gualtieri, G. Artioli, S.M. Clark, Phys. Chem. Miner. 22 (1995) 207.

[47] M.F. Hernández, G. Suárez, M. Cipollone, M.S. Conconi, E.F. Aglietti, N.M. Rendtorff, Ceram. Int. 43 (2017) 2188.

[48] L. Andrini, R. Moreira Toja, M.R. Gauna, M.S. Conconi, F.G. Requejo, N.M. Rendtorff, Appl. Clay Sci. 137 (2017) 233.

[49] R.D. Bonetto, P.E. Zalba, M.S. Conconi, M. Manassero, Rev. Geológ. Chile 30 (2003) 103.

[50] C.-D. Ruan, C.R. Ward, Appl. Clay Sci. 21 (2002) 227. [51] M.F. Serra, M.S. Conconi, M.R. Gauna, G. Suárez, E.F. Aglietti, N.M. Rendtorff, J. Asian Ceram. Soc. 4 (2016) 61. [52] M.F. Serra, M.F. Acebedo, M.S. Conconi, G. Suarez, E.F. Aglietti, N.M. Rendtorff, Ceram. Int. 40 (2014) 1709.

[53] M.F. Serra, M.S. Conconi, G. Suarez, E.F. Agietti, N.M. Rendtorff, Cerâmica 59, 350 (2013) 254.

[54] I.C. Madsen, R.J. Finney, R.C.A. Flann, M.T. Frost, B.W. Wilson, J. Am. Ceram. Soc. 74 (1991) 619.

[55] J.A. González, M. del C. Ruiz, Appl. Clay Sci. 33 (2006) 219.

(Rec. 17/09/2018, Rev. 09/11/2018, 30/11/2018, Ac. 14/12/2018) 